\title{
THE USES AND ABUSES OF POWER: TEACHING SCHOOL LEADERSHIP THROUGH CHILDREN'S LITERATURE
}

\author{
Pat Thomson \\ The University of Nottingham \\ Journal of Educational Administration and History
}

There are relatively few studies of how representations of teachers, schools and educational administrators in popular films and television might be, and are used in leadership preparation.

This paper seeks to add to this small body of work; it reports on an exploratory study of the representation of headteachers in contemporary children's fiction. Thirty one texts are analysed to ascertain key themes and the major characterisations. The paper draws on children's literature scholars to argue that both the historical school story and its contemporary counterpart focus heavily on the power of the head to control the micro-world of the school. Because these fictional accounts deal with issues of power and justice more openly than many mainstream educational administration texts, this makes them particularly useful in the preparation of potential school leaders. 


\section{THE USES AND ABUSES OF POWER: TEACHING SCHOOL LEADERSHIP THROUGH CHILDREN'S LITERATURE}

Educational administration scholars have suggested that films and television texts might be used in leadership preparation programmes as a way of promoting discussion of pressing policy and practice questions (Grant, 2002, Trier, 2002, Trier, 2007). Drawing on scholarly traditions in cultural studies and literary theory, these scholars have either examined film texts to understand the narratives that are told about education, or have deconstructed their discursive representations (Farber et al., 1994, Joseph and Burnaford, 1994, Dalton, 1999, Keroes, 1999, Bulman, 2002, 2005, Ellsmore, 2005, Chennault, 2006). Some of this analysis has included examination of narratives and representations of educational leaders (Thomas, 1998, Smith, 1999, McLay et al., 2001). This work is different from that which examines films and novels in order to understand what they might say about the history of childhood or about schools, teachers or school principals either at particular periods of time or their change over time (e.g. Jones and Davies, 2001, McCulloch, 2009). I write from a cultural and literary tradition, rather than that derived from the discipline of History.

In this paper I seek to add to this minority educational research interest in the pedagogical use of popular texts in leadership preparation. However, rather than look at film and television programmes, I take as my object of study contemporary children's books which feature schools and headteachers. I am particularly interested in their dominant themes and how they portray leaders and the practices of leadership.

In order to understand how contemporary children's stories differ from what are often called 'traditional school stories' - and these are perhaps more familiar to those undertaking leadership programmes than contemporary stories - I begin with a brief discussion of their historical antecedents. I then consider the ways in which modern children's story headteachers are used to embody themes related to power. I conclude with some brief comments about how such texts might be used in leadership preparation. At the outset, I signpost some key theoretical assumptions and the methodological approach that underpins the discussion.

\section{Analysing children's literatures}

This paper needs to be read with a number of caveats in mind. The first set concerns the 'children's literature' which is the subject of analysis. The second set focuses on the difficulties of 'analysis'.

\section{(1) children + literature - an over-determined term}

The notion of children assumes that childhood is a distinctive stage of life. This notion is historically relatively recent (Aries, 1962, Jenks, 1996, James et al., 1998). It has produced both common sense understandings and bodies of expert knowledge (for example in psychology, philosophy, law and education) which describe not only how children come to be and understand the world, but also what does and ought to matter to those who are deemed to be children. These understandings are neither fixed nor agreed. They are culturally contested. They have also changed over time. 
Stories for children have changed in tune with changing views of childhood and children. Alison Lurie (2003) notes that dominant ideas of the kind of world in which children will grow up to be adults are reflected in books intended to instruct them about how to 'be and become'.

The world of Narnia is simple and eternal: goodness, peace and beauty will eventually triumph. The world of Harry Potter is complex and ambiguous and fluid. And in this, of course, it is far more like our own world, in which it is not always easy to tell the ogres from the giants (Lurie, 2003, p. 121).

From offering simple morality tales in which God and Empire triumph (Townsend, 1990, Rose, 2001), children's stories now address a range of much more complex issues. Authoritative commentators Sims and Clare (2000) suggest that as many as 20 per cent of modern children's stories have a school as a major setting for events, while even more have school as a taken-forgranted background to the lives of major characters. Modern children's stories, they say, "often include historical fantasy and horror stories and 'problem' books dealing with modern concerns such as divorce, child abuse and racism" (p. 17).

Like the notion of childhood, what counts as 'literature' is also a product of its time and place. What is understood as being literature, and which texts might be included and excluded in the category, produces considerable debate within scholarly fields and in popular mediatised discussions. Literatures are often discursively divided as highbrow/lowbrow, popular/elite. There are borders of 'taste' which mark off some texts as 'not literature'; exclusions and inclusions are explained in terms of their worth and quality. These of course reflect the cultural interests of dominant social groups and institutions (Bourdieu, 1984). In relation to children, 'good' literatures tend to exclude comics, while books of television series and movies (Grange Hill, Sweet Valley High, Dr Who) are on the edges of acceptance, despite attracting large readerships/sales.

When these two vexed terms - children and literature - come together, further complications arise. Despite the material reality that children are not a homogeneous population, but are diverse (Hunt, 2001), the very notion of children's literature constructs a simple age binarism between adults and children. The term is inescapably embedded in discourses of 'quarantine' of adults from children- as well as in notions of normative development in which texts are seen as 'suitable' for particular ages and reading 'abilities' (Immel, 2009). The age bifurcation ignores the reality that: children's fiction is written by adults who work not only with idealised notions of childhood but also with memories of their own lives as children; children's books are often read by both adults as well as children; and that stories are often the subject of intergenerational events (storytelling, bedtime reading) and conversations (Rose, 1984).

These difficulties permeate any study which purports to speak of a children's literature, including this one. While I reject a simple child/adult binary, I have worked with the notion of 'children's literature' as it is a common term in both everyday life and the academy and I have used book titles which are located in children's literature sections online and in bookshops.

\section{(2) The problem of analysis}

The problem of particularity and partiality riddles contemporary research practices. Not only do researchers always speak from somewhere and at some time (Haraway, 1988, Harding, 1998, 
Lather, 2007), but the texts with which they work are also inevitably of their time. Cultural readings are thus already begun before the reader/researcher opens a book (Said, 1983). There will thus always be difficulties for those who seek to analyse literary texts of any kind. This paper is inevitably produced from the sensibility of a white Western feminist academic of a particular age, space and time and must be read with this in mind.

But there are further points at issue in attempting to come to grips with the interpretation of any literary text, be it written for children or not. This paper works in English literature and cultural studies traditions (see Watkins, 2005 for an explication in relation to studies of children's literature) which posit that texts do not have fixed meanings. Despite the intentions of their producers, readers literally rewrite texts as they read them, making their own meanings as they do so (Barthes, 1975 , de Certeau, 1988). However this does not mean that any reading is as useful as another, or that there can be no critical readings of texts offered. While some texts are more open than others and thus amenable to variable readings, it is also the case that reading is a practice in which the social relations, sense and sensibilities inscribed in a text (see Butts, 1992) is mediated by the reader situated in specific times/places; there are thus patternings in the ways in which readings may be made (Fiske, 1987). Furthermore, all texts have implied readers, and this can be 'read' through critical/deconstructive analysis (Stephens, 1992).

Jacqueline Rose (1984) has argued that most children's books assume a child reader who is innocent, a tabla rasa devoid of morality, politics and sexuality and thus available for instruction. Educators suggest that children's fiction can be seen as pedagogical in that stories provide resources which can be used by the reader to construct the ways in which they think about and potentially act in the world (Moss, 1989, Sarland, 1991). These resources are produced in the text through the mobilisation of dominant and subjugated discourses and their representations (Hall, 1997). It is thus possible to look at children's stories searching for their potential social and political 'effects'.

The approach taken here is neither a reading on behalf of children nor an imaginary of how children might react when they read the text for themselves. Nor is it a study of authorial intentions or an act of literary criticism. It is a political reading from an adult perspective of the social and political inferences and workings of specific narrative representations of the world, in this case schooling (c.f. Keroes, 1999, Gupta, 2003). It is a reading which works with and from a concern about the commercialisation and regulation of children and their education (Giroux, 1997, Steinberg and Kincheloe, 1997, Zipes, 2001), as well as concerns about the ways in which the work of headteachers is increasingly constrained by the tasks of regulation, risk management and surveillance to become an increasingly risky and burdensome practice (Thomson, 2009).

\section{(3) Methodological approach}

With these caveats in mind, I approached the question of representations of headteachers in children's literature.

The sample chosen for analysis was deliberately contemporary - post 1970s - to support the generation of some commonalities around the resources for meaning making offered by the texts (I say more about this later). The books are those generally classified as children's and 
young adult fiction, that is, they are not picture books; they are intended to be read by children anywhere from ages 8 to 14 years, depending on their reading competence and interests.

Given the sheer numbers of books available, determining a corpus was always going to be somewhat arbitrary and the books I have worked with were mostly English language books immediately available from the top forty of an Amazon search conducted around the term 'school story' in January 2008 (see Table 1 for the list). However, given that this is intended as an illustrative analysis, there was no need for a representative sample. There are 11 primary school and 15 secondary representations (head number 2 in table 1 spends five of the six books out of a school setting). They are mostly from the US and Britain; two Australian texts $(8,9)$ are included because they were books I worked with myself as a headteacher in Australia, and they happened to be on my bookshelf. A more recent text (13) was included after I saw a review in a weekend newspaper. The total of texts read for the paper was 30 . A final inclusion at a very late stage was a book (19) written as a result of an artists-in-schools programme and this brought the total number of texts to 31.

\begin{tabular}{|c|c|c|c|c|c|}
\hline Author & Title & Genre & $\begin{array}{l}\text { Publication } \\
\text { details }\end{array}$ & $\begin{array}{l}\text { Name of } \\
\text { head }\end{array}$ & Head type \\
\hline $\begin{array}{l}\text { 1. Cormier, } \\
\text { Robert }\end{array}$ & $\begin{array}{l}\text { The chocolate } \\
\text { war }\end{array}$ & $\begin{array}{l}\text { Social } \\
\text { realist }\end{array}$ & $\begin{array}{l}1975 \\
\text { Fontana: } \\
\text { London }\end{array}$ & $\begin{array}{l}\text { Brother Leon, } \\
\text { potential } \\
\text { head }\end{array}$ & $\begin{array}{l}\text { Sadistic, } \\
\text { authoritarian }\end{array}$ \\
\hline $\begin{array}{l}\text { 2. Cross, } \\
\text { Gillian }(* 6)\end{array}$ & $\begin{array}{l}\text { The demon } \\
\text { headmaster }\end{array}$ & Fantasy & $\begin{array}{l}1982 \\
\text { Oxford } \\
\text { University } \\
\text { Press: Oxford }\end{array}$ & Headmaster & $\begin{array}{l}\text { Evil and } \\
\text { messianic }\end{array}$ \\
\hline $\begin{array}{l}\text { 3. Cutbill, } \\
\text { Andy }\end{array}$ & $\begin{array}{l}\text { A beastly feast } \\
\text { at Baloddin Hall }\end{array}$ & Comic & $\begin{array}{l}2003 \\
\text { Hodder, } \\
\text { London }\end{array}$ & DrSneed & Evil \\
\hline $\begin{array}{l}\text { 4. Dahl, } \\
\text { Roald }\end{array}$ & Matilda & Comic & $\begin{array}{l}1988 \\
\text { Puffin: } \\
\text { Harmondsworth }\end{array}$ & $\begin{array}{l}\text { Miss } \\
\text { Trunchbull }\end{array}$ & $\begin{array}{l}\text { Sadistic, child } \\
\text { hating }\end{array}$ \\
\hline $\begin{array}{l}\text { 5. } \begin{array}{l}\text { Glover, } \\
\text { Sandra }\end{array}\end{array}$ & $\begin{array}{l}\text { The Foxcroft } \\
\text { files }\end{array}$ & $\begin{array}{l}\text { Social } \\
\text { realist }\end{array}$ & $\begin{array}{l}2003 \\
\text { Anderson Press: } \\
\text { London }\end{array}$ & Mr Pikestaff & Dad, modern \\
\hline $\begin{array}{l}\text { 6. Hentoff, } \\
\text { Nat }\end{array}$ & $\begin{array}{l}\text { This school is } \\
\text { driving me crazy }\end{array}$ & $\begin{array}{l}\text { Social } \\
\text { realist }\end{array}$ & $\begin{array}{l}1977 \\
\text { Piccolo: London }\end{array}$ & Mr Davidson & Dad, modern \\
\hline $\begin{array}{l}\text { 7. Kemp, } \\
\text { Gene }\end{array}$ & $\begin{array}{l}\text { The turbulent } \\
\text { term of Tyke } \\
\text { Tyler }\end{array}$ & $\begin{array}{l}\text { Comic, } \\
\text { realist }\end{array}$ & $\begin{array}{l}1977 \\
\text { Puffin: } \\
\text { Harmondsworth }\end{array}$ & Chief Sir & $\begin{array}{l}\text { Remote } \\
\text { authority } \\
\text { figure }\end{array}$ \\
\hline $\begin{array}{l}\text { 8. Lette, } \\
\text { Kathy and } \\
\text { Carey, } \\
\text { Gabrielle }\end{array}$ & Puberty blues & $\begin{array}{l}\text { Social } \\
\text { Realist }\end{array}$ & $\begin{array}{l}1979 \\
\text { McPhee Gribble } \\
\text { Melbourne }\end{array}$ & $\begin{array}{l}\text { The } \\
\text { headmaster }\end{array}$ & $\begin{array}{l}\text { Remote } \\
\text { authority } \\
\text { figure }\end{array}$ \\
\hline $\begin{array}{l}\text { 9. Marchetta, } \\
\text { Melina }\end{array}$ & $\begin{array}{l}\text { Looking for } \\
\text { Alibrandi }\end{array}$ & $\begin{array}{l}\text { Social } \\
\text { realist }\end{array}$ & $\begin{array}{l}1992 \\
\text { Puffin, } \\
\text { Ringwood } \\
\text { Melbourne }\end{array}$ & Sister Louise & $\begin{array}{l}\text { Remote } \\
\text { authority } \\
\text { figure }\end{array}$ \\
\hline
\end{tabular}




\begin{tabular}{|c|c|c|c|c|c|}
\hline 10. Mark, Jan & $\begin{array}{l}\text { Hairs in the } \\
\text { palm of his } \\
\text { hand }\end{array}$ & $\begin{array}{l}\text { Social } \\
\text { realist }\end{array}$ & $\begin{array}{l}1981 \\
\text { Puffin: } \\
\text { Harmondsworth }\end{array}$ & $\begin{array}{l}\text { The } \\
\text { headmaster }\end{array}$ & $\begin{array}{l}\text { Remote } \\
\text { authority } \\
\text { figure }\end{array}$ \\
\hline $\begin{array}{l}\text { 11. McGuire, } \\
\text { Lizzy }\end{array}$ & $\begin{array}{l}\text { New kid in } \\
\text { school }\end{array}$ & $\begin{array}{l}\text { Social } \\
\text { realist }\end{array}$ & $\begin{array}{l}2003 \\
\text { Disney Press: } \\
\text { New York }\end{array}$ & $\begin{array}{l}\text { Principal } \\
\text { Tweedy }\end{array}$ & $\begin{array}{l}\text { Authority } \\
\text { figure }\end{array}$ \\
\hline $\begin{array}{l}\text { 12. McKay, } \\
\text { Hilary }\left({ }^{*} 3\right)\end{array}$ & $\begin{array}{l}\text { Pudding bag } \\
\text { school: The } \\
\text { birthday wish }\end{array}$ & Fantasy & $\begin{array}{l}2003 \\
\text { Hodder: London }\end{array}$ & $\begin{array}{l}\text { Mr Bang } \\
\text { Bang Jones }\end{array}$ & $\begin{array}{l}\text { Authoritarian, } \\
\text { child-hating }\end{array}$ \\
\hline $\begin{array}{l}\text { 13. Mulligan, } \\
\text { Andy }\end{array}$ & Ribblestrop & Fantasy & $\begin{array}{l}2009 \\
\text { Simon \& } \\
\text { Schuster: } \\
\text { London }\end{array}$ & $\begin{array}{l}\text { Dr Norcross- } \\
\text { Webb }\end{array}$ & $\begin{array}{l}\text { Modern, A S } \\
\text { Neill-ish, } \\
\text { otherworldly }\end{array}$ \\
\hline $\begin{array}{l}\text { 14. Peyton, K } \\
\text { M }\end{array}$ & $\begin{array}{l}\text { Who Sir? Me } \\
\text { Sir? }\end{array}$ & $\begin{array}{l}\text { Social } \\
\text { realist }\end{array}$ & $\begin{array}{l}1988 \\
\text { Puffin: } \\
\text { Harmondsworth }\end{array}$ & $\begin{array}{l}\text { The } \\
\text { headmaster }\end{array}$ & $\begin{array}{l}\text { Remote, } \\
\text { concerned, } \\
\text { ineffectual }\end{array}$ \\
\hline $\begin{array}{l}\text { 15. Rowling, J } \\
K(* 6)\end{array}$ & $\begin{array}{l}\text { Harry Potter } \\
\text { and the } \\
\text { philosopher's } \\
\text { stone }\end{array}$ & Fantasy & 1997 & $\begin{array}{l}\text { Professor } \\
\text { Dumbledore }\end{array}$ & $\begin{array}{l}\text { Wise, god- } \\
\text { like, remote, } \\
\text { moral }\end{array}$ \\
\hline $\begin{array}{l}\text { 16. Sacher, } \\
\text { Louis }(* 6)\end{array}$ & $\begin{array}{l}\text { Wayside School } \\
\text { gets a little } \\
\text { stranger }\end{array}$ & Comic & $\begin{array}{l}2003 \\
\text { Harper Collins: } \\
\text { New York }\end{array}$ & $\begin{array}{l}\text { Mr } \\
\text { Kidswatter }\end{array}$ & $\begin{array}{l}\text { Authoritarian, } \\
\text { child hating }\end{array}$ \\
\hline $\begin{array}{l}\text { 17. Snicket, } \\
\text { Lemony }\end{array}$ & $\begin{array}{l}\text { A series of } \\
\text { unfortunate } \\
\text { events: The } \\
\text { austere } \\
\text { academy }\end{array}$ & Fantasy & $\begin{array}{l}2000 \\
\text { Egmont: } \\
\text { London }\end{array}$ & $\begin{array}{l}\text { Count Olaf } \\
\text { Vice Principal } \\
\text { Nero }\end{array}$ & Evil sadistic \\
\hline $\begin{array}{l}\text { 18. Tinkler, } \\
\text { David }\end{array}$ & $\begin{array}{l}\text { The headmaster } \\
\text { went splat! }\end{array}$ & Comic & $\begin{array}{l}1986 \\
\text { Chivers Press: } \\
\text { Bath }\end{array}$ & Killer Keast & Evil sadistic \\
\hline $\begin{array}{l}\text { 19. Wynne- } \\
\text { Willson, } \\
\text { Peter and } \\
178 \text { young } \\
\text { writers }\end{array}$ & $\begin{array}{l}\text { The inflatable } \\
\text { school }\end{array}$ & Comic & $\begin{array}{l}2009 \\
\text { Leighswood } \\
\text { Press: Walsall }\end{array}$ & Mr Stemple & Evil messianic \\
\hline
\end{tabular}

* denotes series of books: only one major title is listed, number read is given in bracket

Table 1: Books analysed

I initially approached each text looking for the genre of story, and the name and characteristics of the headteacher involved (see Table 1). I then worked with the headteacher characteristics in the light of the overall plot of the story to develop a reading about possible 'effects' of the texts. Despite the fact that these stories come from different Western locations, I made the decision to read across the texts in relation to leaders and their practices; there is a strong argument to suggest that schools in the West are dominated by much the same kinds of management practices and change imperatives (e.g. Sahlberg, 2012, Thomson et al., 2013). 
Farber, Provenza and Holm (1994) suggest that popular culture can affect the ways in which people make sense of schooling, showing "the wider patterns of social interaction constituting the purposes, impact and future prospects of schooling" and "conditioning the possibilities of pedagogical relationships" (p. 13). I have interpreted the effects of texts as affordances for making meaning; it was through this lens that I brought my analysis of these texts into conversation with relevant literatures in order to make connections with other analyses of children's literature that focused on schools, children and/or teachers, as well as to find a social theory that might allow some generalisations to be made.

\section{Children's school stories}

The stories that I have analysed must be seen in relation to what is commonly seen as 'the traditional school story'.

School stories flourished in the nineteenth and well into the twentieth century and were originally and largely British in origin. The stories were set in the self-contained middle and upper class worlds of single sex, privately run institutions, often boarding schools (Kirkpatrick, 2000).

Critics (e.g. Auchmuty and Wotton, 2000) agree that the genre is relatively easily divided into stories intended for male and female readers. Early boys' school stories emphasised the manly virtues required for a Christian life while girls' stories focused on the acquisition of womanly accomplishments and the resolution of emotional interpersonal issues. But as the world changed, the stories did too, with boys' stories focusing on the muscular discipline, militarism and tightly contained aggression required for nation and Empire building/maintenance (Townsend, 1990, Grenby, 2008), while girls' stories took on an increasingly 'bluestocking' approach. The school story is often seen as having its heyday in the interwar years when boarding and day school settings were joined by mixed sex and state-run day schools. Representations of stereotypically gendered and raced middle-class privilege nevertheless prevailed (McGillis, 1999, Lehr, 2001) and while boy pupils engaged in various acts of daring and comradeship, in girls' school stories of the time, as Clare and Sims (2000. p. 13) note "it sometimes feels as though every school in the country is either ballet-mad, pony-mad, spy-mad or full of criminals chasing concealed loot".

Kirkpatrick (2000) maintains that, throughout their long life, boys' school stories exhibited a continuous emphasis on the contrast between home and school, the kinds of choices that boys must make when growing up, the nature of responsibility and problems of relationships. Sims and Clare (2000, p. 113) suggest that girls' school stories also put forward a strong notion of honour, in which the community is put above the individual, and girls take responsibility for their actions, own up before being challenged, are honest and trustworthy but do not betray their friends (see also Cadogan and Craig, 1986, Cadogan, 1989). However girls' stories did not always show the same correspondence between school values and prevailing social values as their male counterparts, since they often depicted possible futures other than domesticity. Rosemary Auchmuty (1999) argues that the girls' school story offered resources which allowed young female readers to see women as a priority, engage with a diverse range of ways of being a woman and see fictional peers as resourceful and clever with ambition and potential careers. 
The traditional school story typically relies on the creation of school as a fictional 'little world' in which children are the major characters. Mavis Reimer (2009) notes that the use of "the metaphor of the school as a world implies a correspondence of the school to world systems on other scales and levels" ( $p$ 211). Reimer bases her analysis of the 'little worlds' of children's literature on Foucault's (1977) exegesis of discipline, which argued that societies depend on various modes of discipline and punishment to instill norms of behaviour. While these began as, and still ultimately depend on, the exercise of brute force, they have evolved over time into a variety of institutional forms (prisons, asylums, hospitals, schools), been transmogrified into pastoral as well as coercive modes, and now rely extensively on acts of surveillance, responsibilisation and individuation to ensure compliance through instilling particular ways of thinking/acting. The purpose of these 'technologies' is to ensure that the government of the population, and citizenship and freedom, are the product of self, rather than externally imposed discipline - although that always remains an option for those who do not 'learn' to make the right self-governing choices. While power is exercised top-down, it also circulates throughout society in order to create order rather than chaos, and to allow for checks and balances on social norms. Reimer sees the 'little world' of the fictional school as a representation of a highly normative Foucualdian institution. As preparation for the 'real world', the school story is "motivated by the need for order and comprehension"; it is an "expression of the desire to master the environment by placing what is outside inside where it can be contained or managed" (p. 212). This is accomplished by plots that seek to

explicitly map the geographies and boundaries of the school ... demonstrate the principles by which power is exercised and distributed, ... enact rules that assign morality and immorality to conduct; (and) institute the marks of belonging and exclusion... (p. 212)

In school stories, Reimer notes, headteachers are often distant and remote, and engaged in continued surveillance and acts of punishment on the student population. Students recognize the headteacher's authoritative gaze and its intent; it governs their actions. They also know that any indiscipline will incur sanctions from afar (p. 211).

M. O. Grenby (2008) also offers a Foucauldian reading of the school story and the ways in which the apparently impartial authority of the headteacher functions to promote socialization and individuation. Grenby highlights the school's inculcation of self-discipline through its focus on

authority and obedience (which) lie at the heart of the school story. Superficially teachers wield power and pupils are coerced to obey, usually by the threat of severe punishment ( $p$. 95)

School stories demonstrate, he suggests, how children and young people are "to integrate successfully into a community and to reconcile the demands of self and society" (p. 113). The great freedoms afforded by boarding schools provide the site in which children must establish a balance between the obedience of childhood and the independence of adulthood (p. 95). Grenby argues that the

connection between the head and God has become almost a standard feature of the school story... they are loving and benevolent but just and severe, demanding obedience and ready to inflict harsh punishment or forgive (p. 97) 
Through an analysis of the imperial school stories of Rudyard Kipling, Grenby establishes that boys "matured by a combination of submission and defiance" to their teachers, while "a remote headmaster ...sits in judgment even on his teaching staff" (p. 96).

Both Reimer and Grenby note that these 'little world' school stories are potentially highly conservative. They suggest that the acquisition of self-discipline through conforming and integrating into an established community with its discursively gendered, classed and raced school ethos may well be as restrictive as enabling of freedom, no matter how pastoral the exercise of discipline and how veiled the gaze (c.f. Hunter, 1994). As Reimer puts it

Criticisms of school as places of injustice, unhappiness and coercion have featured in narratives from the beginning of the genre, but such critiques have been a comparatively thin thread, more typical is the story in which the new scholar learns first to understand, then to accept, and finally to excel at, the ways of the strange world she is entering.... Giving young readers pictures of complete, self sufficient and contained systems, the school story seeks to persuade them that they too have a place in the world before them (p. 224).

In this enterprise, the headteacher in the traditional school story, no matter how authoritarian or how kind and empathetic, embodies the rule of law and society at large. Power/knowledge resides in his/her person and leadership/management.

I will suggest that this is an argument which has resonance in and relevance to the corpus of modern children's stories I examined. However before I deal with the corpus, I put my analysis in its wider context and thus signpost some key issues about contemporary children's literature.

\section{The modern children's story and representations of the headteacher}

Children's literature has taken on literary forms associated with modernism - parody and pastiche for example, with hefty doses of inter-textual references to music, social events and films. Child readers and their adult guides are expected to know these references and to enjoy the added layers of meaning that they bring to the narrative. The modern school story is also likely to use a range of literary genres.

But 'modern', as has already been suggested, also refers to the settings and plots of children's stories. The range of settings is more likely to cover mixed sex and comprehensive schools for example and include children from working class, mixed heritage and immigrant backgrounds as well as those of the white middle class. The themes within the 'little worlds' of school are also likely to be more 'adult' in their concerns than has been traditional. The modern children's story is set in an age which is seen as less certain and more risky than ever before (c.f. Giddens, 1990, Jameson, 1991, Beck, 1992). Within children's literatures, the implied modern child reader who lives in such uncertain times is one who not only experiences more than children in previous times, but also needs to know more about the world as it is and as it might be. Themes such as racism, divorce, death, mental illness, politics, and sexuality are all now grist to the children's story, whether it is in comedy, horror, fantasy or social realist genres. Child readers are expected to not only know what these themes are about, but also to use the resources in the stories to help make sense of and manage these things in their own lives. 
Yet, while the school is often seen as a site of almost exclusively modern teen culture and preoccupations - Puberty Blues (8) for example is concerned almost entirely with 'identity' issues emanating from teenage surf cultures and boy-girl relationships; Looking for Alibrandi (9) focuses on identity issues for a bicultural young woman dealing with separated parents and teenage depression and suicide - a contemporary twist is only partially realized in the characterisations of teachers and headteachers. There are strong continuities with traditional school stories.

Anne Trousdale (1994) analysed modern children's picture books and their representations of teachers. She noted that the relationships between teachers and heads featured in several. With one exception all of the texts showed female teachers and male heads in primary school settings. Trousdale's analysis centres on the power (im)balance between the two staff positions, with the majority of the texts showing, she suggests, the head - even when he is friendly, clever and resourceful - as remote and producing anxiety in the teacher. She also found instances of a head who was ineffectual and boring, and another who was cowed by his former teacher. Both the effectual and ineffectual representations of the teacher-head relationship show strong resonances with the traditional school story. It is the distance in the relationship, the remoteness and the potential for the head to discipline (or not) that marks the continuity. By contrast, Trousdale located one text which showed a female headteacher and teacher having a more equal relationship, with the head being helpful to the teacher, rather than being simply a random classroom visitor demanding attention and needing to be impressed. In her corpus of 47 picture books, this was the single exception to show power being shared rather than exercised hierarchically.

Trousdale's analysis has strong resonance with the corpus of texts I examined. Many of the stories addressed themes related to power and morality - the clash of tradition and modernity $(4,8,13)$, the struggle for democracy and freedom against authority $(1,2,7,15,17)$ and for kindness over brutality $(1,3,4,5,7,12,16,18)$. In these themes, teachers and particularly headteachers often represented the 'bad' part of the binary at stake. In my sample, nine headteachers were evil and sadistic, while another seven were remote authority figures whose job was to pass impartial judgment at some point in the plot.

I examine these dominant representations in more detail after a brief discussion of some contemporary twists in plots and settings. Here I return to the corpus of stories, discussing overarching themes.

\section{Contemporary twists on power}

Modern children's stories in the corpus take up contemporary educational references and themes: school-business partnerships, pedagogies, and the work-home life of students and headteachers.

Corrupt relationships between businessmen and headteachers who have the autonomy to make financial decisions for their 'devolved' schools appear in two texts in the corpus. In $A$ beastly feast at Culoddin Hall, headteacher Dr Sneed (3) has made an alliance with an evil grocer Mr Whicker to set up a factory to turn children into sausages, while Mr Stemple (19) from The inflatable school, a headteacher invented by children working with a writer, wants to turn his school into an academy sponsored by a business with whom his family in local government has 
a long-term mutually profitable relationship. Child readers, and the adults with whom they might be in conversation, are not only expected to understand that these commercial relationships exist in education, but also that they have as much potential for corruption as for good (c.f. Hood, 1998).

They are also expected to appreciate that there is more than one way for teaching and learning to be organized. Dr Norcross-Webb (13), the otherworldly head of Ribblestrop Academy, a small privately funded school for wayward children and orphans, has strong pedagogical views which run counter to the back-to-basis approaches espoused by policymakers in many jurisdictions (see e.g. Apple, 2001). Despite his ongoing financial worries emanating from his inability to attract paying customers, Dr Norcross-Webb favours unfashionable child-centred approaches which involve students in real-life activities: this means literally rebuilding the school and engaging in lengthy outdoor hikes. In the Harry Potter books, J. K. Rowling also mounts a critique of dull, didactic text-book driven approaches to learning through the introduction of a rival to headteacher Professor Dumbeldore in the form of the loathsome toadlike Ministry of Magic appointed Dolores Umbridge (Rowling, 2003, see also Thomson, $2009 \mathrm{Ch}$. 3).

Two of the texts in the corpus $(5,6)$ have child heroes whose father is the school head. In This school is driving me crazy, Nat Hentoff's (6) headteacher father and son plot revolves around the son's fight to expose the bullying that his father cannot see. Sandra Glover (5), in The foxfire files, has her parent-child conflict set amid fears of the outcomes of a school inspection and the son's efforts to clear the name of an at-risk pupil unfairly accused by his headteacher father of committing acts designed to damage the school's reputation. In both cases the parent-child relationship comes into conflict through the pupil-headteacher struggle. Readers are expected to understand and empathise with the difficulties for children who attend a school in which their parent is headteacher; they must manage relationships with the universal authority figure acting 'in loco parentis' as well as the biological parent in the family. The headteacher's child must also manage relations with peers who see the head as authoritarian and someone to be feared/satirised, and the child of the head as potentially able to carry home student-oriented stories of events and to curry favours on students' behalf. Readers are also privy to heads' dilemmas when it is their child who is the most defiant of their authority in the school. In these books, child and adult readers see heads both front and backstage (Goffman, 1969, Goffman, 1971) and are expected to learn from the details of the emotional management of the blurred relationships between home and school. Such blurring is a feature of many modern workplaces (Nippert-Eng, 1996, Hochschild, 1997).

These three aspects of representations of headteachers' work in the modern children's story do demonstrate some differences with their traditional predecessors. They are reflections of current policy agendas, and in the case of the third aspect a new secular view of heads as both public/private people. However, there is both difference and continuity in the ways in which modern children's literature deals with the headteacher's role. A Foucauldian approach to the corpus suggests that in the modern children's story the head, like his/and occasionally her traditional predecessor, is almost always represented as the symbol of societal power to discipline and punish.

\section{It's about power}


In some children's stories, the head appears largely as an office door which students must avoid, or as a remote figure at ceremonial occasions such as assemblies $(7,9,14)$. Sometimes heads are represented as having unseen but nevertheless material power, as in Mr Kidswatter (16) in the Wayside school series who frequently appears as a disembodied voice crackling over a PA system whose speakers are located in every classroom. This distantiated head often equates to someone who is out of touch with the world of students, as is the head in Puberty Blues (8) who warns students in assembly that they need to watch out in public places for people who might stick needles into their unsuspecting arms in order to turn them into drug addicts.

Students are sent to the remote head for punishment when they are judged by the school staff who are directly responsible for them - their class teachers - to be unable to discipline themselves. When Tyke Tyler (7, The turbulent term of Tyke Tyler) is sent to her head, simply called Chief Sir to indicate his relationship to all of the other powerful Sirs in the school, his detachment is signified through a steely voice, cold blue eyes, formalised syntax and caustic remarks. The remoteness of the head, and the lack of relationship that the students have with the head, makes venturing into the generally closed office a frightening occasion.

Many heads are represented as having panoptic powers. Grenby (2009) notes that, in J. K. Rowling's Hogwarts (15), children are largely able to discipline themselves. As long as they obey basic regulations they are "largely autonomous agents free to choose their own activities and rules" (p. 96). However, headteacher "Dumbledore's ability to be in the right place at the right time suggests an all seeing eye" (p. 99) and readers "are left to deduce that all the school's ghosts, sentient portraits and so on act as informants... all is known to the authorities... the pupils regard themselves as always being under a monitoring gaze" (p. 100). Their freedom to act is therefore always taken in the knowledge of the power of the unseen watching head.

Many of the plots of the children's stories in the corpus revolve around the ways in which power is used to ill or better effect. Strongly normative stories show that:

\section{(1) totalitarianism is wrong}

Gillian Cross' (2) demon headmaster is known simply as The Headmaster; his appearance is the signifier of his inhuman nature and inhumane practices - he occupies a sterile and unnaturally tidy office; he is tall and thin, dressed immaculately in a black suit and a black academic gown which hangs like a predatory crow's wings; his hair is almost colourless and he has paper-white skin and pallid lips and long ivory-coloured hands. Readers are left to make the association with vampires and warlocks for themselves. Children are hypnotised for most of the day and sit in the hall receiving subliminal instructions. The demon headmaster exercises control at other times through a set of brainwashed prefects who recite his words mindlessly - this is discipline achieved at the expense of the freedom to choose. The demon headmaster plans to use this neat and tidy fascistic school as the basis for a scheme to run the nation on similar lines. He is overcome by a group of resistant children who create dis-order in the school, thus demonstrating the Foucauldian principle that power circulates throughout an organisation and can be used to increase as well as reduce freedom. Cross' liberatory lesson stands in contrast to Robert Cormier's Chocolate War (1) where dissident students do not overturn a totalitarian bullying culture, and where it seems the abuse of power from the top is an ongoing feature of school life. 


\section{(2) power and acting badly/wrongly often go together}

The comic genre in the corpus almost invariably has a cruel or evil headteacher outwitted by children $(3,4,16,18,19)$ sometimes assisted by a lone, sensible adult. Most adults in these stories are either unable to see or are overcome by the actions of the bad headteacher. In David Tinkler's The headmaster went splat! (18) Killer Keast is characterised as a head who has bad moods, wild moods, savage moods and Grade Z Killer moods, during which teachers go white and shiver as he glares and gathers his academic robes about him like raven's wings. Early in the book he refuses to listen to a child defending himself against an unjust accusation and Tinkler comments directly to the reader about the reasons for this - those who are called to the position of headteacher are attracted by the power they will have.

If Killer Keast had been a calm, easy-going sort of chap, he'd have listened to what Kevin had to say. But Killer was not calm; nor was he particularly thoughtful; and no-one had ever described him as easy-going. He should really have been a pirate chief or the leader of a band of brigands - but he wasn't. Instead he was a headmaster. A lot of other headmasters are just the same; there just aren't many jobs going for pirate chief types nowadays, so these pirate chief types have to become headmasters instead. I expect you've noticed this yourself. (Tinkler, 1986, p. 21)

The likening of Keast to a pirate is intended to flag to well-read modern children that he may not be all bad and, like Captain Hook, he may have other sides to his personality that will be revealed (in Hook's case an unhappy childhood and unexpected softnesses). In Tinkler's story, the real villain of the piece is a robber who is outwitted by children, assisted by Rose the mudwrestling policewoman. In the denouement, Killer Keast is shown to be human and in need of support and assistance - a Kitten Keast. Thereafter, he is said to alternate between his Killer and Kitten personae, balancing excesses of force with more moderate behaviours, a feat he accomplishes with the assistance of children who knew better than he did about what really matters in the problems of bad behaviour.

\section{(3) pastoral power is preferable to overt force}

Some children's stories are designed to show the benefits of the gentle use of pastoral power. Child readers are offered this lesson so that they might also choose to discipline themselves and others in this way.

Miss Trunchbull (4), one of only two female heads in the corpus, is un-natural; she is physically masculinist, formidable and repulsive. Roald Dahl, the author of Matilda, the book in which she features, describes her body as muscular, with a bull neck, big shoulders, thick arms, massive thighs, sinewy wrists and powerful legs. She is alleged to have acquired these characteristics in a previous career as an athlete. She has an obstinate chin, a cruel mouth and small arrogant eyes and wears an outlandish outfit of smock, breeches and brogues. Miss Trunchbull is fond of whirling small girls around by their pigtails and incarcerating small boys in nail-studded cupboards. Dahl is careful to note, in this morality tale of the triumph of kindness over cruelty, that Miss Trunchbull is an exceptional headteacher. 
... most headteachers are chosen because they possess a number of fine qualities. They understand children and have the children's best interests at heart. They are sympathetic. They are fair and they are deeply interested in education. Miss Trunchbull possessed none of these qualities and how she ever got her present job was a mystery (Dahl, 1989, p 76)

Someone like this was however at hand.

Much of Dahl's story revolves around the chief character Matilda's precocious defiance of Miss Trunchbull and her defence of Miss Honey, a young and pretty teacher possessed of a Madonna face, a fragile body and a gentle forgiving nature who was universally adored by small children. After a series of clashes with the sadistic Miss Trunchbull, Matilda and her friends eventually win out by publicly humiliating, frightening and shaming their massive enemy. She is of course replaced by the angelic Miss Honey in the triumph of good over evil, self discipline over punishment, pastoral power over brute force.

\section{In sum}

In the corpus of modern children's stories then, there is a strong advocacy of liberal governmentality in which individuals are expected to be responsible and free, as long as their choices of behaviour conform to acceptable norms (see Rose, 1999, Miller and Rose, 2008). Plots teach that unreasonable norms, those which curtail responsible freedoms, must be and can be overcome and that children who make the wrong choices must learn to be responsible. In each of these two options, it is the headteacher who is the ultimate authority with the power to sanction and reward, to discipline and punish.

However, as noted earlier, the need for children to acquire self discipline is not because of the need for adult citizens to serve God and Empire as in the traditional school story, but rather because the reflexive modern citizen needs to serve and save themselves in a world where adults are often fallible, self serving and myopic, and sometimes venal, corrupt and brutal, and where social institutions are fragile, unstable, callous and unscrupulous.

\section{Bringing children's literature to leadership preparation}

To those concerned with understanding the logos and telos of educational administration, it is immediately clear that children's stories 'come clean' about headteachers' work in ways that many mainstream educational leadership texts do not (Bates, 1987, Bates, 1993). In the field, there are relatively few books or articles which talk about headteacher practice as the exercise of power, that address the just or unjust ends to which the exercise of power can be directed, and the effects that abuses of power can have within the school community (they do exist of course, see for example Smyth, 1993, Maxcy, 1995, Gunter, 1997, Blackmore, 1999, Samier and Stanley, 2008). Indeed, in my personal experience, when the question of power is raised with practicing headteachers, it is often regarded as a 'dirty word'.

Yet, as these children's books suggest, the exercise of power through the institution of schooling may well be a reality which is recognized by children, if these texts are to be believed. Power permeates the way that they inhabit their everyday school world. The implied reader in the corpus I have examined is a child who: recognises that power can be used wisely and to ethical ends - or not; who understands that pupils can use their individual and collective power 
to challenge school/headteacher authority if that course of action is morally required; and who sees that the judicious use of pastoral power is preferable to symbolic and actual violence.

Critical and post-critical voices in educational administration are few and far between (Donmoyer et al., 1995), and their contributions are often regarded as unpalatable precisely because, like children's books, they address questions of power and interest in the school. Discussion of shared leadership for example generally ignore the reality that heads cannot relinquish the power that is vested in the role (Hatcher, 2005, Fitzgerald and Gunter, 2008), while empirical studies show that staff, parent and student participation in decision making is highly framed and constrained, despite rhetorics of empowerment and democracy (Thomson

and Sanders, 2009). But because these children's books confront the question of power, and do so in a way which is both entertaining and relatively quick to read, they may allow an initially tangential approach to the subject to be broached in the educational administration classroom. If this is the case, then our school leaders may be better for facing and working through the question of their own power over others.

\section{References}

Apple, M., 2001. Educating the "right" way. Markets, standards, God and inequality New York \& London: Routledge Falmer.

Aries, P., 1962. Centuries of childhood New York: Vintage Books.

Auchmuty, R., 1999. A world of women. Growing up in the girls' school story London: The Women's Press.

Auchmuty, R. \& Wotton, J., 2000. The encyclopaedia of school stories. Volumes 1 and 2 Aldershot, Burlington USA: Ashgate.

Barthes, R., 1975. The pleasure of the text New York: Hill and Wang.

Bates, R., 1987. Corporate culture, schooling, and educational administration. Educational Administration Quarterly, 23, 79-115.

Bates, R., 1993. On knowing: cultural and critical approaches to educational administration. Educational Management and Administration, 21, 171-176.

Beck, U., 1992. Risk society. Towards a new modernity London: Sage.

Blackmore, J., 1999. Troubling women. Feminism, leadership and educational change Buckingham: Open University Press.

Bourdieu, P., 1984. Distinction. A social critique of the judgment of taste Boston: Harvard University Press.

Bulman, R.C., 2002. Teachers in the 'hood. Hollywood's middle class fantasy. The Urban Review, 34, 251276.

Bulman, R.C., 2005. Hollywood goes to high school. Cinema, schools and American culture New York: Worth.

Butts, D. (ed.) (1992) Stories and society. Children's literature in its social context, London: Macmillan.

Cadogan, M., 1989. Chin up, chest out Jemima! A celebration of the schoolgirls' story Bath: Girls Gone By Publishers.

Cadogan, M. \& Craig, P., 1986. You're a brick Angela! The girls' story 1839-1975, 2 ed. London: Victor Gollancz.

Chennault, R.E., 2006. Hollywood films about schools. Where race, politics and education intersect New York: Palgrave Macmillan.

Dahl, R., 1989. Matilda London: Puffin Books.

Dalton, M., 1999. The Hollywood curriculum. Teachers and teaching in the movies New York: Peter Lang.

De Certeau, M., 1988. The practice of everyday life Los Angeles: University of California Press.

Donmoyer, R., Imber, M. \& Scheurich, J. (eds.) (1995) The knowledge base in educational administration. Multiple perspectives, New York: State University of New York Press.

Ellsmore, S., 2005. Carry on teachers! Representations of the teaching profession in screen culture Stoke on Trent: Trentham. 
Farber, P., Provenzo, E.J. \& Holm, G. (eds.) (1994) Schooling in the light of popular culture, Albany: State University of New York Press.

Fiske, J., 1987. Television culture London: Methuen.

Fitzgerald, T. \& Gunter, H., 2008. Contesting the orthodoxy of teacher leadership. International Journal of Leadership in Education, 11,331-340.

Foucault, M., 1977. Discipline and punish. The birth of the prison, 1991 ed. London: Penguin.

Giddens, A., 1990. The consequences of modernity Cambridge: Polity Press.

Giroux, H., 1997. Channel surfing. Race talk and the destruction of today's youth New York: St Martins Press.

Goffman, E., 1969. The presentation of self in everyday life London: Penguin.

Goffman, E., 1971. Relations in public New York: Harper \& Row.

Grant, P., 2002. Using popular films to challenge preservice teachers' beliefs about teaching in urban schools. Urban education, 37, 77-95.

Grenby, M.O., 2008. Children's literature Edinburgh: Edinburgh University Press.

Gunter, H., 1997. Rethinking education. The consequences of Jurassic management London \& Herndon: Cassell.

Gupta, S., 2003. Rereading Harry Potter Basingstoke: Palgrave Macmillan.

Hall, S., 1997. Representation: Cultural representations and signifying practices Buckingham: Open University Press.

Haraway, D., 1988. Situated knowledges: The science question in feminism and the privilege of partial perspective. Feminist Studies, 14, 575-599.

Harding, S., 1998. Is science multicultural? Postcolonialisms, feminisms, and epistemologies Bloomington: Indiana University Press.

Hatcher, R., 2005. The distribution of leadership and power in schools. British Journal of Sociology of Education, 26, 253-267.

Hochschild, A.R., 1997. The time bind. When work becomes home and home becomes work New York: Metropolitan Books.

Hood, C., 1998. The art of the state. Culture, rhetoric and public management Oxford: Clarendon Press.

Hunt, P., 2001. Children's literature Oxford: Blackwell.

Hunter, I., 1994. Rethinking the school. Subjectivity, bureaucracy, criticism Sydney: Allen \& Unwin.

Immel, A., 2009. Children's books and constructions of childhood. In M.O. Grenby \& A. Immel (eds.) The Cambridge companion to children's literature. Cambridge: Cambridge University Press, 19-34.

James, A., Jenks, C. \& Prout, A., 1998. Theorising childhood New York: Teachers College Press.

Jameson, F., 1991. Postmodernism, or the cultural logic of late capitalism Durham, NC: Duke University Press.

Jenks, C., 1996. Childhood London: Routledge.

Jones, K. \& Davies, H., 2001. Representing education 1969-1980: notes on "Kes" and "Grange Hill". History of Education, 30, 141-151.

Joseph, P. \& Burnaford, G. (eds.) (1994) Images of school teachers in twentieth century America: paragons, polarities and complexities, New York: St Martins Press.

Keroes, J., 1999. Tales out of school. Gender, longing and the teacher in fiction and film Carbondale, ILL: Southern Illinois University Press.

Kirkpatrick, R., 2000. Introduction. In R. Kirkpatrick (ed.) The encyclopaedia of boys' school stories. Aldershot: Ashgate, 1-12.

Lather, P., 2007. Getting lost. Feminist efforts toward a double(d) science New York: State University of New York Press.

Lehr, S. (ed.) (2001) Beauty, brains and brawn: The construction of gender in children's literature, Portsmouth, NH: Heinemann.

Lurie, A., 2003. The perils of Harry Potter. In A. Lurie (ed.) Boys and girls forever. Children's classics from Cinderella to Harry Potter. London: Chatto and Windus, 113-123.

Maxcy, S., 1995. Democracy, chaos, and new school order Thousand Oaks, CA: Corwin Press.

Mcculloch, G., 2009. The moral universe of Mr Chips: veteran teachers in British literature and drama. Teachers and Teaching: Theory and Practice, 15, 409-420.

McGillis, R. (ed.) (1999) Voices of the other: Children's literature and the postcolonial context, New York: Garland. 
Mclay, M., Brown, M. \& Ralph, S., 2001. Leadership through the lens: images of headteachers in three television documentaries. Management in Education, 155, 31-34.

Miller, P. \& Rose, N. (eds.) (2008) Governing the present, Cambridge: Polity.

Moss, G., 1989. Un/Popular fictions London: Virago Press.

Nippert-Eng, C., 1996. Home and work. Negotiating boundaries through everyday life Chicago: University of Chicago Press.

Reimer, M., 2009. Traditions of the school story. In M.O. Grenby \& A. Immel (eds.) The Cambridge companion to children's literature. Cambridge: Cambridge University Press, 209-225.

Rose, J., 1984. The case of Peter Pan and the impossibility of children's fiction London: Macmillan.

Rose, J., 2001. The intellectual life of the British working class London: Yale University Press.

Rose, N., 1999. Governing the soul. The shaping of the private self, 2nd ed. London: Free Association Books.

Rowling, J.K., 2003. Harry Potter and the order of the phoenix London: Bloomsbury.

Sahlberg, P., 2012. Finnish lessons: What can the world learn from educational change in FInland? London: Routledge.

Said, E., 1983. The world, the text and the critic Cambridge MA: Harvard University Press.

Samier, E. \& Stanley, A. (eds.) (2008) Political approaches in educational leadership and management, London: Routledge.

Sarland, C., 1991. Young people reading: culture and response Milton Keynes: Open University Press.

Sims, S. \& Clare, H., 2000. Introduction. In S. Sims \& H. Clare (eds.) The encyclopaedia of girls' school stories. Aldershot, Hants, England: Ashgate.

Smith, P., 1999. Sex, lies and Hollywood's administrators. The (de) construction of school leadership in contemporary films. Journal of Educational Administration, 37, 50-65.

Smyth, J. (ed.) (1993) A socially critical view of the self managing school, London: Falmer Press.

Steinberg, S. \& Kincheloe, J. (eds.) (1997) Kinder-culture. The corporate construction of childhood, Boulder CO: Westview Press.

Stephens, J., 1992. Language and ideology in children's fiction London: Longman.

Thomas, R., 1998. As they are portrayed: principals in film. International Journal of Educational Management, 12, 90-100.

Thomson, P., 2009. School leadership - heads on the block? London: Routledge.

Thomson, P., Gunter, H. \& Blackmore, J., 2013. Series foreword. Critical Leadership Series. London: Routledge.

Thomson, P. \& Sanders, E., 2009. Creativity and whole school change: an investigation of English headteachers' practices. Journal of Educational Change, 11, 63-83.

Tinkler, D., 1986. The headmaster went splat! Bath: Chivers Press.

Townsend, J.R., 1990. Written for children London: Bodley Head.

Trier, J., 2002. Exploring the concept of 'habitus' with preservice teachers through the use of popular school films. Interchange, 33, 237-260.

Trier, J., 2007. Teaching theory through popular texts. Teaching Education, 18, 151-166.

Trousdale, A., 1994. Teacher as gatekeeper. Schoolteachers in picture books for young children. In P.B. Joseph \& G. Burnaford (eds.) Images of schoolteachers in twentieth-century America. New York: St Martins Press, 195-214.

Watkins, T., 2005. Space, history and culture. The setting of children's literature. In P. Hunt (ed.) Understanding children's literature. 2nd ed. London: Routledge, 50 -71.

Zipes, J., 2001. Sticks and stones: The troublesome success of children's literature from Slovenly Peter to Harry Potter London: Routledge. 